\title{
Expectations and Understanding of Learning in Practice: Student Speech and Language
} Therapists' and Practice Educators' Perspectives of Learning

\author{
Karen Davies* \\ University of Manchester, United Kingdom \\ Fiona Kevan \\ University of Manchester, United Kingdom \\ Emma Ormerod \\ University of Manchester, United Kingdom
}

\begin{abstract}
Research in speech and language therapy education has focussed on investigating models of clinical placements, rather than how learning is optimised in practical settings. A distinction has been made in practice-based learning in medical education between 'capability' and 'competency', urging educators to prioritise learning that enables problem solving and application of theory. We know little about student speech and language therapists' (SLTs) and educators' perception and expectations of clinical learning in placement and how this relates to capability. We investigated student SLTs' and educators' beliefs and experiences of successful learning in clinical settings and how they perceived their learner/educator roles using a qualitative study. Data was gathered from 28 students and educators using individual interviews and focus groups. The data was investigated using thematic analysis. Educators see their role as facilitators, developing core skills such as clinical reasoning, understanding professional identity and gaining independence. Some educators see this as a co-learning model, creating opportunities for their own learning. Students' conceptions change during clinical placements, from focussing on their own development to seeking to understand the client's perspective as well as identify needs, and respond with well-reasoned options for intervention. Aiming to equip SLT learners to be capable professionals, able to apply skills of clinical reasoning, is considered a core skill for SLT educators. Developing models for clinical placements informed by understanding how students learn to become capable could enhance the readiness of student SLTs to enter professional practice.
\end{abstract}

Keywords: clinical learning; placements; practice educators; student speech and language therapists

${ }^{*}$ Corresponding Author: Karen Davies, University of Manchester, PSSRU, Ellen Wilkinson

Building, Oxford Road, Manchester M15 6JA United Kingdom

Journal URL: https://publications.coventry.ac.uk/index.php/pblh

Email:karen.davies-3@manchester.ac.uk

Davies, K., Kevan, F. and Ormerod, E. (2019) 'Expectations and understanding of learning in practice: Student speech and language therapists' and practice educators' Perspectives of Learning'. International Journal of Practice-based Learning in Health and Social Care, 7 (1), 1-17 https://doi.org/10.18552/ijpblhsc.v7i1.502 


\section{(c) (i) $(9)$} distributed under the terms of the Creative Commons Attribution Attribution-Non-Commercial No Derivatives 4.0 International License (https://creativecommons.org/licenses/by-nc-nd/4.0/ ), which permits unrestricted non-commercial use, distribution, and reproduction in any medium, provided the original work is properly cited and is unaltered. 


\section{Introduction}

Learning is often a collaborative process, mediated and structured by an educator, leading to changes in learners' knowledge and understanding. Major changes in thinking, according to conceptual change theorists in educational research, suggest that existing and naïve conceptual frameworks become restructured in response to changes in understanding (Vosniadou 2014). Clinical placements provide the context for student speech and language therapists (SLTs) to develop their conceptions of practice, with the partnership between practice educators, university educators and students forming the keystone for enabling the transition from learner to capable, competent professional. Responsibility for teaching student SLTs during clinical placement transfers to experienced clinicians supervising learning in routine practice settings. We know relatively little about practice educators' perceptions of teaching or students' views of learning within clinical placements in speech and language therapy or how this may contribute to conceptual change. Understanding the perspectives of students and educators, revealed through their own voices, should help us to understand how to maximise learning and actively promote conceptual change during clinical education.

\section{Background}

Researchers in health care argue that educating for 'capability' as well as competency is essential: rather than simply supporting new practitioners to acquire a set of skills, we should be equipping them to employ those skills in high-level problem solving and application of theory in response to complex factors found in practice (Fraser and Greenhalgh 2001, Higgs et al. 2018). Learning in practical settings provides the ideal opportunity for developing capable, as well as competent, practitioners. There are well-defined standards of practice that determine overarching themes for undergraduate speech and language therapy education in the UK (Health and Care Professions Council 2017). In addition, the quantity of practical learning, often expressed as hours in clinical placements, is determined by the professional organisation (Royal College of Speech and Language Therapists 2003). These tend to focus on measurable competencies and skills, but less frequently refer to the characteristics of capability, defined as "the extent to which individuals can adapt to change, generate new knowledge, and continue to improve their performance" (Fraser and Greenhalgh 2001: 799).

Interest in approaches that promote capability have received little attention in speech and language therapy as research and professional debate tends to be dominated by an interest in models of clinical placements (Bhagwat et al. 2018, Briffa and Porter 2013). Research has focused on evaluating the merits of block or weekly placements, comparing peer to one-to-one placements, or considering the benefits of role-emerging placements (Price and Whiteside 2016, Sheepway, Lincoln, and Togher 2011, Thew, Hargreaves and Cronin-Davis 2008). Focussing on the context for learning provides little evidence about which approach provides a better learning experience (Briffa and Porter 2013, Mok, Whitehill, and Dodd 2008, Sheepway, Lincoln, and Togher 2011). The absence of evidence of how educators promote learning in placement and relative absence of the student voice in research (Davenport et al. 2017) suggest a gap in our understanding (Sheepway, Lincoln, and Togher 2011). Similarly, the relative paucity of training for SLTs as educators prompts questions about how practice educators themselves can acquire the skills to teach the next generation of SLTs (McAllister 2005). The authors' personal experience, drawing on extensive experience of working in the $\mathrm{NHS}$ in the UK, indicates that student SLTs often receive a relatively conventional model of practice education using 1:1 teaching in placement, in pre-arranged clinical situations that may not accurately reflect usual clinical intervention. There may be limited opportunities to contribute to developing wider skills such as educating carers, delivering group intervention or participating in multi-disciplinary teams.

In an era of increased demand on practice educators, we need to consider ways that we can maximise student learning that encourages application of theory and knowledge to supporting 
the complex needs of people with communication and swallowing difficulties. This study was designed to answer two research questions:

(1) To what extent do student SLTs and educators understand learning in terms of becoming capable?

(2) How do student SLTs and educators perceive their learner/educator roles in practice education?

\section{Method}

Qualitative methods were employed (semi-structured interviews and focus groups) to capture the views of undergraduate SLTs and practice educators. Ethical approval was provided by the University using a standard online ethics decision tool. Ethical procedures were followed with written study information, informed written and verbal consent (recorded for telephone interviews), anonymised data and secure storage of data.

\section{Recruitment and participants}

Student SLTs (Year 1 to Year 4), attending one pre-registration undergraduate programme for SLTs in the UK, and practice educators associated with the programme were invited to participate in the study. Invitations were circulated by the first researcher, who was not known to the participants, via email using student and practice educator networks available as part of existing partnerships used by the education programme. Volunteers contacted the researcher and appointments were made to meet the researcher, for face-to-face interviews with students, and for one-to-one telephone interviews or focus groups with practice educators.

Table 1: Participants in interviews and focus groups

\begin{tabular}{|ll|}
\hline Participants & Number of participants \\
\hline Interview with students & 12 \\
Interview with practice educators (2 face-to-face and 2 telephone interviews) & 4 \\
Focus groups with practice educators (2 groups of 6) & 12 \\
\hline Total & $\mathbf{2 8}$ \\
\hline
\end{tabular}

\section{Data collection and analysis}

Each interview and focus group followed a topic guide prepared with guidance from both practice and university educators. There were nine open-ended questions investigating perceptions and experience of learning during placements, expectations of responsibilities of students and educators, and challenges encountered. Each individual interview lasted 20-30 minutes, whilst focus groups lasted 30-60 minutes. Interviews were audio-recorded to enable detailed and accurate analysis. Records of audio recordings were anonymised and did not contain identifiable information. The data were coded directly from the audio recordings using thematic analysis (Braun and Clarke 2006, Green et al. 2007). The themes were derived using the constant comparison method (Boeije 2002), identifying similarities and differences between the views expressed in the recordings.

The reliability of the themes from the focus groups were checked with one other researcher who had observed the focus groups. Practice educators from the speech and language therapy programme were asked to comment on the authenticity of the themes from the student interviews on the basis of their professional experience. 


\section{Results}

\section{Practice educators' views of student education on placement}

Theme 1: Practice educators perceive their roles as facilitator, educator, role model and evaluator

Practice educators frequently referred to facilitating student learning by modelling therapy activities, leading clinical discussions and enabling students to undertake therapy tasks (Table 2). Facilitating was depicted as prompting and supporting, whilst teaching was described by some educators as a more directive activity, as illustrated by the following comment: 'You're more of a facilitator and ask them to talk you through their actions and decision.'

References to teaching frequently described an activity that involved explanation about what should be done or showing the steps of a process and then watching the student do the activity as a 'model, do and reflect' approach. In spite of the overlap evident in the way educators described facilitating and teaching, some practice educators did not perceive their role as that of a teacher: 'Yes, they are learning from me but l'm not a teacher'.'

Educators also described an evaluator role, giving informal feedback on students' practice and encouraging students to reflect on their own practice. Occasionally educators referred to asking students to evaluate the SLT's practice, with the explicit intention of encouraging students to develop skills in critically analysing practice, making judgements about what they were observing and learning to articulate their own feedback: 'I'm asking for feedback as well, scary but fundamental to what we do such as giving feedback to parents.'

Some emphasised the difficulty they experienced making judgements about students' development, and clearly felt unprepared for assessing an individual's learning, as illustrated: 'That idea that you're judging someone is scary.'

Table 2: Educator perception of their role

\begin{tabular}{|c|c|c|}
\hline Theme & Subtheme & Quotations \\
\hline Educator & $\begin{array}{l}\text { Explaining } \\
\text { Questioning } \\
\text { Directing } \\
\text { Linking theory to practice }\end{array}$ & $\begin{array}{l}\text { Yes, they are learning from me but l'm not a teacher } \\
\text { Explicitly showing them what they need to do }\end{array}$ \\
\hline Facilitator & $\begin{array}{l}\text { Case discussion } \\
\text { Modelling practice } \\
\text { Prompting practical skills } \\
\text { Encouraging student to comment } \\
\text { on SLT's practice } \\
\text { Structuring observation }\end{array}$ & $\begin{array}{l}\text { I try to get them doing hands on therapy as soon as } \\
\text { possible as that's what it's about } \\
\text { At other times you're more of a facilitator and ask them to } \\
\text { talk you through their actions and decision } \\
\text { Model, do, reflect } \\
\text { You need to have hands on to feel confident }\end{array}$ \\
\hline Role model & $\begin{array}{l}\text { Showing how to focus on client } \\
\text { and not themselves } \\
\text { Displaying what it means to be an } \\
\text { SLT }\end{array}$ & Learn how to be a therapist" \\
\hline Evaluator & $\begin{array}{l}\text { Assessing student level/needs } \\
\text { Judging student readiness } \\
\text { Judging level of confidence, stage } \\
\text { of training, personality } \\
\text { Monitoring progress } \\
\text { Providing feedback }\end{array}$ & $\begin{array}{l}\text { That idea that you're judging someone is scary } \\
\text { Always explore what they know or don't know } \\
\text { Trying to get what her knowledge was and how confident } \\
\text { she felt }\end{array}$ \\
\hline
\end{tabular}


Theme 2: Practice educators aim to develop student core capabilities, client-specific skills and professional identity

Practice educators described their aims and expectations for students in terms of (i) gaining 'core' skills, (ii) learning specific clinical skills relevant to their own client group, and (iii) developing professional practice and identity (Table 3). Educators described supporting students to apply skills flexibly and encouraging learners to adapt to situational changes and limitations.

Table 3: Practice educator aims and expectations for student education

\begin{tabular}{|c|c|c|}
\hline Theme & Subtheme & Quotations \\
\hline \multirow[t]{7}{*}{ Developing student core skills } & $\begin{array}{l}\text { Interpersonal skills } \\
\text { Building relationships with clients } \\
\text { and wider team } \\
\text { Greeting client, eye contact, } \\
\text { respectful interchange, answering } \\
\text { the phone }\end{array}$ & $\begin{array}{l}\text { Lovely to watch student with good } \\
\text { interpersonal skills }\end{array}$ \\
\hline & Self determination & Students shouldn't be spoon-fed \\
\hline & Able to seek guidance & $\begin{array}{l}\text { Good students know what they } \\
\text { want from a placement }\end{array}$ \\
\hline & Learn from feedback & \\
\hline & & $\begin{array}{l}\text { Engaging and willing to learn, and } \\
\text { they go away and do things, find }\end{array}$ \\
\hline & $\begin{array}{l}\text { Relates practice to previous } \\
\text { experience and knowledge }\end{array}$ & out more \\
\hline & Organised & $\begin{array}{l}\text { Used good records to build her } \\
\text { planning and guided decision } \\
\text { making for the future }\end{array}$ \\
\hline \multirow[t]{3}{*}{ Developing clinical skills } & $\begin{array}{l}\text { Assessment: identifying speech } \\
\text { and language needs } \\
\text { Goal setting: targets and designing } \\
\text { practical } \\
\text { activities to achieve targets }\end{array}$ & $\begin{array}{l}\text { Linking what they've learnt at } \\
\text { University, the theory, with what } \\
\text { you actually do when a person is } \\
\text { sat in front of you }\end{array}$ \\
\hline & $\begin{array}{l}\text { Knowledge: relevant to specific } \\
\text { clients }\end{array}$ & $\begin{array}{l}\text { Try to tease out what they can do } \\
\text { for the patient and compare with } \\
\text { what I do }\end{array}$ \\
\hline & $\begin{array}{l}\text { Flexible practice: adapting to client } \\
\text { and context }\end{array}$ & \\
\hline \multirow[t]{2}{*}{$\begin{array}{l}\text { Encouraging professional identity } \\
\text { and professionalism }\end{array}$} & $\begin{array}{l}\text { Understanding values of } \\
\text { profession } \\
\text { Introduction to SLT community of } \\
\text { practice }\end{array}$ & \multirow[t]{2}{*}{$\begin{array}{l}\text { Mechanics can be learnt but } \\
\text { important to convey principles and } \\
\text { values; understanding the clients } \\
\text { are people (including } \\
\text { family) } \\
\text { Being realistic about expectations } \\
\text { and holding the child at the centre }\end{array}$} \\
\hline & $\begin{array}{l}\text { Ensuring student is ready for the } \\
\text { workplace: time keeping, dress, } \\
\text { attitude to colleagues }\end{array}$ & \\
\hline
\end{tabular}

Practice educators referred to three core skills: interpersonal skills, showing initiative (selfdetermination), and organisation. Basic interpersonal skills, such as the ability to relate to people, were considered a prerequisite for clinical placements. Learning to manage clinical interviews and discussions with patients and clients, family members and other professionals 
were presented as a key part of placement learning. As one SLT observed, her aim was 'reorienting' the student so they put the client at the centre of their thinking and practice, in contrast to focusing exclusively on their own development.

Educators expected student SLTs to approach learning using self-determination in taking the initiative, responding to feedback and guidance and changing their practice accordingly. Students were expected to identify their own learning needs and take responsibility for investigating and questioning what they encountered in placements. Educators expected students to explicitly relate their practical experience to the theory they were learning during formal teaching on campus, as well as drawing on previous experience in other settings.

Finally, educators expected students to be well organised, prepared for the placement, keeping records of experience and activities, as well as having some knowledge of the client group and setting. The following quotation illustrates the importance that educators placed on this: 'Students who are less organised don't make as much progress.'

In referring to 'professional' practice, educators alluded to two distinct aspects of learning to become a professional. First, they mentioned professionalism, expecting the student to conduct themselves appropriately in terms of dress, attendance and behaviour with patients and clients. Second, they referred to supporting the students' process of transitioning from perceiving themselves as students to seeing themselves as SLTs, developing a sense of identity as an SLT and learning to see themselves as colleagues and part of the SLT community of practice. The majority of educators interviewed were eager to focus on enabling student SLTs to understand the concept of being an SLT, expressed as gaining the principles, values and professional ethos that they considered at the heart of being an SLT. As one practice educator commented,

Mechanics can be learnt but important to convey principles and values, understanding that clients are people (including their family). It's being realistic about expectations and holding the child at the centre.

\section{Theme 3: Good teaching on placement is tailored to the student, mutually beneficial, and encourages clinical reasoning based on principles of the profession}

In response to questions about what made good practice education for student SLTs, educators highlighted four essential elements: (i) designing activities according to the level of the student; (ii) utilising reciprocal learning; (iii) creating opportunities for clinical reasoning through discussion and debate; and (iv) promoting professional principles and ethos (Table 4).

Initially, educators referred to being responsive to the learner in terms of practical organisation, such as timetabling, identifying supervisors and clinics, assigning clients and signposting resources. This included an introduction to the department and to local processes and policies such as care pathways. As educators considered the question in more depth, they referred to the style of teaching; the majority mentioned responding to the student, assessing 'level of experience, knowledge and confidence and jointly agreeing aims' for placements in a responsive and cooperative process. They did not refer to using the intended learning outcomes from the undergraduate programme to determine learning on placement.

Many indicated that a good placement was characterised by a collaborative approach where both educator and student learnt from each other:

They say 'you know [what] we were talking about' and 'you really wanted to know about this' and 'look what I found' and that just really impacts on your practice as well as your relationship with your student. 
Educators also referred to shared problem-solving as a process to encourage clinical discussion. This provided opportunities for students to contribute evidence from research and theory, with educators and students applying this to cases assigned to the student. Educators perceived the process of explaining, justifying and reasoning with a student as affording the opportunity to reflect more carefully, adding to the quality of their own clinical reasoning, 'Actually just having a student in the room makes me question, why am I doing this?'.

Finally, many educators believed a good placement provided an induction into the professional world of speech and language therapy, with a responsibility to share the values of the profession and motivate the student to feel positive and enthusiastic about practising as a SLT.

Table 4: Practice educators' views of promoting student learning

\begin{tabular}{|c|c|c|}
\hline Theme & Subtheme & Quotations \\
\hline Responsive to learner & $\begin{array}{l}\text { Agreeing preferences and aims } \\
\text { for placement } \\
\text { Adjusting learning context and } \\
\text { content } \\
\text { Staged process of providing } \\
\text { support and enabling } \\
\text { independence, balancing } \\
\text { oversight and student } \\
\text { independence }\end{array}$ & $\begin{array}{l}\text { Always explore what they know } \\
\text { or don't know } \\
\text { Adjust expectations according to } \\
\text { 'how quickly they jump in to } \\
\text { something' which depends on } \\
\text { personality and experience }\end{array}$ \\
\hline $\begin{array}{l}\text { Opportunities for reciprocal } \\
\text { learning }\end{array}$ & $\begin{array}{l}\text { Sharing knowledge: } \\
\text { theory/research and experience } \\
\text { Providing reciprocal feedback } \\
\text { after activities; educator to } \\
\text { student and also student to } \\
\text { educator }\end{array}$ & $\begin{array}{l}\text { I can learn a lot from a student - } \\
\text { they help you } \\
\text { Actually just having a student in } \\
\text { the room makes me question } \\
\text { 'why am I doing this?' } \\
\text { I love having students cos it } \\
\text { really does make me question } \\
\text { my practice } \\
\text { They're up to date with the } \\
\text { theory which we aren't } \\
\text { I'm asking for feedback as wee- } \\
\text { scary but fundamental to what } \\
\text { we do such as giving feedback } \\
\text { to parents }\end{array}$ \\
\hline Promoting clinical reasoning & $\begin{array}{l}\text { Not "delivering knowledge' but } \\
\text { encouraging students to reason } \\
\text { and explain rationale for } \\
\text { intervention }\end{array}$ & $\begin{array}{l}\text { Guiding not quizzing, but } \\
\text { reasoning using 'why' and then } \\
\text { reflecting } \\
\text { I help them apply knowledge to } \\
\text { real people and contexts }\end{array}$ \\
\hline $\begin{array}{l}\text { Foregrounding professional } \\
\text { ethos and principles }\end{array}$ & $\begin{array}{l}\text { Include student in all clinical } \\
\text { reasoning activities } \\
\text { Educator sharing enthusiasm for } \\
\text { profession }\end{array}$ & $\begin{array}{l}\text { Letting them participate in all the } \\
\text { things we do } \\
\text { Hopefully inspiring them to love } \\
\text { SLT }\end{array}$ \\
\hline
\end{tabular}

In summary, practice educators expected student SLTs to be prepared, with a theoretical understanding relevant to their client group, and capable of building relationships with clients. 
Their approach to teaching assumed a facilitative style, with the intention of nurturing clinical skills and problem-solving relevant for clinical reasoning.

\section{Students' views of learning on clinical placement}

\section{Theme 1: Student SLTs expect to gain practical therapy skills}

Student SLTs' expectations are loosely formulated initially and they are unclear about the SLT role or what will be expected of them on placement, typically commenting, 'I don't know what I'm expecting'. The majority expected to gain confidence in interacting with clients, understanding the SLT role and practical therapy skills (Table 5). They were keen to be involved and working with patients, clients, carers and the wider team and contributing to clinical discussions. They consistently referred to the opportunity of working with patients and clients in a 'hands-on' capacity and putting their 'theoretical' learning into practice. Typical responses referred to 'having a go', 'try out different things' and 'seeing different things'. Nevertheless, they readily acknowledged that this was daunting, commenting that they would feel 'outside their comfort zone'.

Table 5: Student SLTs' perception of learning on placement

\begin{tabular}{|c|c|c|}
\hline Theme & Subtheme & Quotations \\
\hline \multirow[t]{2}{*}{ Learning what to do } & Learning the technical skills what SLTs do & $\begin{array}{l}\text { Seeing what they do in practice } \\
\text { I haven't actually seen what's } \\
\text { really done } \\
\text { Being able to do more practical } \\
\text { skills like doing a transcription or } \\
\text { assessment }\end{array}$ \\
\hline & Learning to apply theory to practice & Seeing the theories coming to life \\
\hline \multirow[t]{2}{*}{$\begin{array}{l}\text { Learning how to } \\
\text { think as an SLT }\end{array}$} & Clinical reasoning & $\begin{array}{l}\text { Making therapy decisions and } \\
\text { goals according to the patient }\end{array}$ \\
\hline & Person-centred & $\begin{array}{l}\text { Looking at the holistic case of the } \\
\text { patient }\end{array}$ \\
\hline $\begin{array}{l}\text { Learning how to be } \\
\text { confident in the role } \\
\text { of SLT }\end{array}$ & $\begin{array}{l}\text { Confident in practice } \\
\text { Understanding range of work }\end{array}$ & $\begin{array}{l}\text { Confidently assessing a range of } \\
\text { patients } \\
\text { Seeing lots of different roles that } \\
\text { SLTS might do }\end{array}$ \\
\hline
\end{tabular}

Many students referred to good placements as an environment that encouraged investigation through learning to question, implying an emerging appreciation of learning how to engage in clinical reasoning. Whilst some clearly welcomed challenges and recognised the benefits of being pushed to think more carefully about practice, they also admitted that this could feel demanding, as noted by one, it 'can be hard to say why are you doing that'.

Findings from interviews with students indicated a distinction between the expectations of inexperienced and experienced student SLTs. Inexperienced students tended to focus on learning the technical skills of what SLTs do whilst final-year student SLTs referred to learning clinical practice, such as assessment, planning, intervention and discharge, but emphasised overarching themes, such as learning to reflect on the impact of their practice on patients and clients and gaining confidence to practice independently. For example, one student described developing her skills in reflecting, commenting that at first, she reflected very little, but now, I am thinking of every little thing. How did what I planned for the session impact the patient and what does that mean I do next.' 
Theme 2: Students' perception of the educator role as demonstrator, facilitator, instructor and evaluator

Student SLTs' expectations indicated that they perceived educators as: (i) demonstrator, reflecting their interest in gaining practical skill; (ii) facilitator, who encourages and questions; (iii) educator, providing direction and explanation; and (iv) evaluator, assessing the student's progress and providing feedback (Table 6).

Table 6: Students' perception of educators' role

\begin{tabular}{|c|c|c|}
\hline Theme & Subtheme & Quotations \\
\hline Demonstrator & Showing techniques & $\begin{array}{l}\text { Showing detail of what should } \\
\text { be done from planning to writing } \\
\text { reports } \\
\text { You're going to be like them in } \\
\text { the future } \\
\text { Seeing what they do in practice } \\
\text { Not like a pedagogical teacher, } \\
\text { more like showing you the way }\end{array}$ \\
\hline Facilitator & $\begin{array}{l}\text { Prompting discussion } \\
\text { Encouraging student to question } \\
\text { 'Pushing' student understanding- } \\
\text { depends on gaining the right balance of } \\
\text { being supportive and pushing student }\end{array}$ & $\begin{array}{l}\text { Learning from them but also } \\
\text { learning to question } \\
\text { Being comfortable enough to } \\
\text { ask questions } \\
\text { You're put on the spot and you } \\
\text { have to think of the theory to } \\
\text { answer it } \\
\text { Pushing you to develop so that } \\
\text { at the end of this placement I } \\
\text { feel ready to have a job }\end{array}$ \\
\hline Educator & $\begin{array}{l}\text { Articulating clinical reasoning and } \\
\text { decision making } \\
\text { Directly explaining actions and rationale } \\
\text { Help student understand the link between } \\
\text { theory and practice }\end{array}$ & $\begin{array}{l}\text { Lapping up the language she } \\
\text { was using } \\
\text { Explained her role, explained } \\
\text { everything to us, how the school } \\
\text { works, explained the child's } \\
\text { needs } \\
\text { Regard as teacher, in a way, } \\
\text { but won't be taking everything } \\
\text { as gospel } \\
\text { Directing me to evidence and } \\
\text { guidelines; to explain things } \\
\text { rather than just letting me } \\
\text { observe from the side }\end{array}$ \\
\hline
\end{tabular}

The student SLTs described a wide range of teaching approaches, ranging from 'showing', 'explaining', and 'questioning', but these were often linked in their dialogue to students' own role as learners who were gaining confidence in questioning and seeking feedback from clients and educators. 
Theme 3: Changes in thinking from focussing on what needs doing to centring on client need

Student SLTs described many challenges of learning on placement, often finding it difficult to balance the practical requirements with managing patient and client needs (Table 7).

Table 7: Student SLTs' perception of changes in their thinking

\begin{tabular}{|c|c|c|}
\hline Theme & Subtheme & Quotations \\
\hline \multirow[t]{3}{*}{$\begin{array}{l}\text { Learning to focus on } \\
\text { patient/carer and } \\
\text { context }\end{array}$} & $\begin{array}{l}\text { Empathising with people's } \\
\text { experience of communication } \\
\text { breakdown and associated } \\
\text { frustrations }\end{array}$ & $\begin{array}{l}\text { I didn't understand that until I saw } \\
\text { patient in real life } \\
\text { settings...complex cases, just } \\
\text { remembering to include everyone. } \\
\text { I was lucky to see from being } \\
\text { admitted to into the community. } \\
\text { Over time I got to know his wife } \\
\text { and family and I was able to use } \\
\text { that in sessions, to plan goals } \\
\text { together and doing joint sessions } \\
\text { with the rest of the team }\end{array}$ \\
\hline & $\begin{array}{l}\text { Learning to look at the whole } \\
\text { case and ensuring goals are set } \\
\text { according to right thing for } \\
\text { individual }\end{array}$ & $\begin{array}{l}\text { Thinking bigger-more than just } \\
\text { what I'm doing to help the person } \\
\text { impairment-wise, how they're } \\
\text { going to function in everyday life }\end{array}$ \\
\hline & $\begin{array}{l}\text { Considering how SLT practice } \\
\text { impacts on patients and clients }\end{array}$ & $\begin{array}{l}\text { How to be in the paediatric } \\
\text { setting, how to structure sessions, } \\
\text { how to present the session to the } \\
\text { child, how to achieve my goals } \\
\text { with the child. It was so much } \\
\text { harder...I think it impacted on how } \\
\text { much I could achieve in that } \\
\text { placement }\end{array}$ \\
\hline \multirow[t]{3}{*}{ Learning to reflect } & $\begin{array}{l}\text { Understanding oneself and } \\
\text { impact on practice }\end{array}$ & $\begin{array}{l}\text { I'm quite a shy person, so that's } \\
\text { challenging }\end{array}$ \\
\hline & Learning from clients & $\begin{array}{l}\text { Parents seem to be watching you, } \\
\text { really judging you. Even if you get } \\
\text { everything right, it can be quite } \\
\text { scary }\end{array}$ \\
\hline & $\begin{array}{l}\text { Learning by discussion with } \\
\text { peers }\end{array}$ & \\
\hline \multirow[t]{3}{*}{$\begin{array}{l}\text { Learning to be } \\
\text { independent }\end{array}$} & $\begin{array}{l}\text { Expected to make independent } \\
\text { decisions }\end{array}$ & $\begin{array}{l}\text { Biggest learning curve l've ever } \\
\text { had }\end{array}$ \\
\hline & Accepting greater demands & Step outside comfort zone \\
\hline & $\begin{array}{l}\text { Understanding own role in work } \\
\text { context }\end{array}$ & \\
\hline
\end{tabular}


Nevertheless, they also referred to changes in their thinking during placement and reported marked changes in their outlook. The most prominent change described by some students was learning to consider the patients' and clients' perspective, the wider influences surrounding care and the impact of intervention. These were presented as important steps that altered the individual's perception of being an SLT, as well as their approach to their own clinical practice. The following quotation expresses the sense in which understanding the patient and the working context influenced the student SLT's contribution:

I didn't understand that until I saw patient in real life settings... complex cases, just remembering to include everyone. I was lucky to see [a patient] from being admitted to [hospital and then returning] into the community. Over time I got to know his wife and family and I was able to use that in sessions, to plan goals together and doing joint sessions with the rest of the team.

\section{Discussion}

This article investigated the views of teaching during placements as part of speech and language therapy pre-registration education from practice educator and student SLT perspectives. It explored perceptions of roles, expectations and challenges. This discussion identifies some points of similarities and differences between student SLTs and practice educators, presented as four key features related to teaching and learning in clinical practice: (i) practice educators prioritise core skills such as clinical reasoning and focusing on capability, whilst students concentrate on learning what to do, expecting to gain specific competences; (ii) practice educators and students favour a facilitative approach to teaching; (iii) educators perceive themselves as co-learners with students, whilst students rarely expressed an expectation that they could contribute to SLT practice in placement; and (iv) educators aim to nurture independent practitioners, explicitly encouraging students to consider themselves as professional SLTs.

\section{Prioritising core skills to build capability in contrast to learning what to do}

The development of clinical reasoning was a priority for many practice educators. They referred to clinical reasoning without referring directly to capability, but indicated an expectation that students engaged in higher levels of critical thinking, integrating knowledge, skills and personal qualities in response to complex situations. Research on clinical reasoning in speech and language therapy is relatively sparse (American Speech-Lanquage-Hearing Association 2008, McAllister and Rose 2000). However, the related concepts of clinical reasoning and capability are beginning to be discussed in the wider field of practice education in health (Christenson and Jenson 2018, Higgs et al. 2018), recommending models of practice education that prioritises teaching for capability. Nevertheless, there are indications in the literature that students find learning clinical reasoning difficult (Delany and Golding 2014). Students describe struggling to see the thinking processes that experienced clinicians used, with researchers applying the terms 'invisible' and 'inaccessible' to express students' experience of understanding clinicians' thinking (Delany and Golding 2014). Moreover, qualified SLTs tend to privilege "practice knowledge" gained from other clinicians and prefer a "give it a go" approach (McCurtin and Carter 2015: 1145) which may suggest that articulating clinical thinking is less frequently prioritised in routine practice. In the current study, student SLTs tended to focus on learning technical skills: what SLTs do, such as how they manage the interaction with a client or the process of conducting an assessment. Learning to question and respond to questioning, as part of clinical reasoning, was described by students as a significant change in their thinking as they gained experience and appreciated the wider client perspective. Students referred to thinking more flexibly about practice over time in response to client needs rather than following a rigid or prescribed protocol, suggesting that learning that is more than mere acquisition of knowledge. Previous research investigating how educators enable students to change their thinking and adopt frameworks that enhance clinical reasoning indicate that they regard clinical reasoning as a priority (Ginsberg, Friber, and Visconti 2016). From a theoretical perspective, such changes in 
thinking may signify that conceptual change has occurred (Vosniadou 2013), where an individual's preconceptions about a phenomenon, in this case, the role and practice of the SLT, are revealed and challenged, leading to restructuring of concepts and an entirely new conceptual framework (Sinatra and Mason 2013).

\section{Practice educators and students favour a facilitative approach to teaching}

Both educators and students perceived teaching as a facilitative process, referring to modelling practice, prompting practical skills and engaging in case discussions. There were many examples of educators referring to learning that involved a high level of student involvement in investigating evidence independently, posing questions, drawing inferences and learning from collaborative discussion in order to develop student understanding. Previous research has outlined the characteristics of teaching for capability, detailing the features of learning contexts involving problem solving, reflection and reciprocal learning which are characteristic of a facilitative approach to teaching (Christensen and Jensen 2018). The findings from this study suggest that practice educators in the UK are eager to develop their role as facilitators, with many instinctively employing methods that encourage a deep approach to learning (Trigwell, Prosser, and Waterhouse 1999). This contrasts with the conclusion from a previous study in Australia that indicated that educators assumed the role of 'supervisor' rather than 'educator' (McAllister 1997), overseeing practice but rarely assuming a teaching role. In some examples, practice educators continued to assume that teaching was a directive method involving the formal delivery of knowledge.

\section{Educators perceive themselves as co-learners with students, whilst students rarely expressed an expectation that they could contribute to SLT practice in placement}

There were a number of educators who considered working with students as an opportunity for their own learning, describing a reciprocal process that helped them gain knowledge and, in some cases, change their own practice in response to new evidence presented by student SLTs practice educators' description of collective learning aligned with the concept found in the literature on communities of practice (Wenger 2011), based on sharing knowledge between student and educator. Students were seen as contributing up-to-date knowledge from research, while practice educators prompt enquiry through relating research to clinical cases. Developing a belief that student SLTs can be an asset and a resource within a community of practice has the potential to enhance learning for all participants. Given that students rarely expressed their role as contributors to such a community of learning, educators may need to find ways to ensure students adjust their conception of themselves from a burden for busy practitioners, to a co-learner within a professional community.

\section{Educators aim to nurture independent practitioners explicitly encouraging students to think of themselves as professional SLTS}

Both educators and students referred to a process of initiation into the professional world of speech and language therapy. Educators aimed to move students to autonomous professionals, able to 'fly solo' in readiness for a career as a professional SLT. Learning on placement included teaching the principles and values of the profession as well as learning the correct way of doing clearly defined activities such as assessment and case planning. This is in keeping with the growing belief that professionalism cannot be absorbed implicitly during placements but should be taught and assessed explicitly (Mason et al. 2016).

Three implications from these findings could contribute to the development of practice-based teaching in speech and language therapy. First, enabling practice educators to develop their conception of teaching for capability, explicitly revealing the thinking that underpins their clinical reasoning (McCurtin and Carter 2015) could encourage students to focus on deepening their understanding of clinical issues as well as acquiring practical skills. Previous research showed that adopting a 'think aloud' technique made clinical reasoning visible to students (Delany and 
Golding 2014), creating opportunities for them to develop their understanding and potentially prompting significant changes to the conceptual frameworks that shape their learning for capability in practice. In order for speech and language therapy programmes to educate for capability (Fraser and Greenhalgh 2001) practice educators may need to develop a more detailed understanding of teaching and how to enable students to engage in clinical reasoning.

Secondly, this study indicates that practice educators anticipate that student SLTs should be ready to learn core skills during placement. A previous study identified that student readiness was important for educators (Chipchase et al. 2012), suggesting that innovative teaching methods could be considered to develop core skills related to personal attributes and clinical reasoning before placements begin. Learning is often mediated through the use of 'simulated learning environments' or 'simulated patients/clients' in medical education (Bradley 2006) but few studies have investigated the use of simulation in speech and language therapy programmes. Early findings from research shows that simulated learning environments can be beneficial in changing student thinking and behaviour in the profession (MacBean et al. 2013). Researchers argue that simulation provides the opportunity to practise skills in a safe and supportive environment, possibly proving as beneficial as placement learning (Hill et al. 2014).

Finally, exploring how to monitor and measure change in student thinking and behaviour during clinical learning could sharpen the focus of all those involved in student education. Whilst preregistration speech and language therapy programmes have clearly articulated intended learning outcomes for each unit of study, practice educators and student SLTs rarely referred to published intended learning outcomes to articulate the learning in this study. There is scope within SLTs' education in the UK for considering how we align teaching methods employed on placement with our stated intended learning outcomes and in turn how this aligns with assessment of practical learning (Joseph and Juwah 2012). More consistent use of innovative teaching methods, such as e-supervision (Carlin et al. 2013) and video feedback, as a tool for analysing changes in student SLTs' thinking and behaviour (Fadde and Sullivan 2013, Fukkink, Trienekens, and Kramer 2011) could be useful additions to pre-registration programmes. The merits of video as a teaching tool to develop capability through changing thinking and practice has been investigated in teacher education (Gaudin and Chaliès 2015, Tripp and Rich 2012) but remains largely unexplored in speech and language therapy.

We acknowledge that our study has limitations related to relatively small numbers of participants who were self-selecting and therefore potentially subject to recruitment bias. Nevertheless, we believe the study has given an opportunity for the educator and student voice to be heard, promoting the priorities that educators and students identify themselves.

In conclusion, previous literature suggests that clinical education in speech and language therapy is undervalued (Lincoln and McCabe 2005). Our study highlights the value educators ascribe to their role in teaching on placement, with an emphasis on facilitating student SLTs to acquire core skills. It has provided an agenda for future research and development, including developing practice educators' understanding of teaching and learning, investigating activities such as simulated learning environments for preparing student SLTs before clinical placements and adopting new technology to encourage learning that promotes capability as well as technical skills. Furthermore, the application of social learning theory to understand how learners' conceptions change in clinical placement could contribute to our understanding of the effectiveness of clinical education in the profession. Focussing beyond equipping student SLTs to be competent practitioners, who know what to do, we might also aspire to educating capable graduate professionals who approach each new clinical situation with the skills to engage in the critical thinking that complex cases demand of qualified SLTs.

\section{Acknowledgements}

With thanks to the students, Speech and Language, and therapists and clinical tutors who so readily shared their experiences and thoughts with the researchers. 


\section{References}

American Speech-Language-Hearing Association (2008) Clinical supervision in speechlanguage pathology. Position Statement. available from http://www.asha.org

Bhagwat, M., Hewetson, R., Jones, L., Hill, A., Nunn, J., Tosh, R., and Cahill, L. (2018) 'Comparison of paired and single clinical placement models: A time-use analysis'. International Journal of Language and Communication Disorders, 53 (3), 468-479 https://doi.org/10.1111/1460-6984.12360

Boeije, H. (2002) 'A purposeful approach to the constant comparative method in the analysis of qualitative interviews'. Quality and Quantity, 36 (4), 391-409 https://doi.org/10.1023/A:1020909529486

Bradley, P. (2006) 'The history of simulation in medical education and possible future directions'. Medical Education, 40 (3), 254-262 https://doi.org/10.1111/j.13652929.2006.02394.x

Braun, V., and Clarke, V. (2006) 'Using thematic analysis in psychology'. Qualitative Research in Psychology, 3 (2), 77-101 https://doi.org/10.1191/1478088706qp063oa

Briffa, C., and Porter, J. (2013) 'A systematic review of the collaborative clinical education model to inform speech-language pathology practice'. International Journal of SpeechLanguage Pathology, 15 (6), 564-574 https://doi.org/10.3109/17549507.2013.763290

Carlin, C.H., Boarman, K., Carlin, E., and Inselmann, K. (2013) 'The use of e-supervision to support speech-language pathology graduate students during student teaching practica'. International Journal of Telerehabilitation, 5 (2), 21-31 https://doi.org/10.5195/IJT.2013.6128

Chipchase, L.S., Buttrum, P.J., Dunwoodie, R., Hill, A.E., Mandrusiak, A., and Moran, M. (2012) 'Characteristics of student preparedness for clinical learning: clinical educator perspectives using the Delphi approach'. BMC Medical Education, 12 (1), 1-9 https://doi.org/10.1186/1472-6920-12-112

Christensen, N., and Jensen, G.M. (2018) 'Developing clinical reasoning capability' in Clinical Reasoning in the Health Professions E-Book. ed. by Higgs et al. Elsevier Health Sciences, 427-434

Davenport, R., Hewat, S., Ferguson, A., McAllister, S., and Lincoln, M. (2017) ‘Struggle and failure on clinical placement: A critical narrative review'. International Journal of Language and Communication Disorders, 53 (2), 218-227 https://doi.org/10.1111/1460$\underline{6984.12356}$

Delany, C., and Golding, C. (2014) 'Teaching clinical reasoning by making thinking visible: An action research project with allied health clinical educators'. BMC Medical Education, 14 (1), 1-10 https://doi.org/10.1186/1472-6920-14-20

Fadde, P., and Sullivan, P. (2013) 'Using interactive video to develop pre-service teachers' classroom awareness'. Contemporary Issues in Technology and Teacher Education, 13 (2), 156-174. Retrieved from https://www.citejournal.org/volume-13/issue-2$13 /$ general/using-interactive-video-to-develop-preservice-teachers-classroomawareness 
Fraser, S.W., and Greenhalgh, T. (2001) 'Coping with complexity: Educating for capability'. BMJ: British Medical Journal, 323 (7316), 799-803 https://doi.org/10.1136/bmi.323.7316.799

Fukkink, R.G., Trienekens, N., and Kramer, L.J. (2011) 'Video feedback in education and training: Putting learning in the picture'. Educational Psychology Review, 23 (1), 45-63 https://doi.org/10.1007/s10648-010-9144-5

Gaudin, C., and Chaliès, S. (2015) 'Video viewing in teacher education and professional development: A literature review'. Educational Research Review, 16, 41-67 https://doi.org/10.1016/j.edurev.2015.06.001

Ginsberg, S.M., Friberg, J.C., and Visconti, C.F. (2016) 'Diagnostic reasoning by experienced speech-language pathologists and student clinicians'. Contemporary Issues in Communication Science and Disorders, 43, 87-97

Green, J., Willis, K., Hughes, E., Small, R., Welch, N., Gibbs, L., and Daly, J. (2007) 'Generating best evidence from qualitative research: The role of data analysis'. Australian and New Zealand Journal of Public Health, 31 (6), 545-550 https://doi.org/10.1111/j.1753-6405.2007.00141.x

Health and Care Professions Council (2017) Standards of Education and Training. available from https://www.hcpc-uk.org/resources/standards/standards-of-education-and-training/ [4th December 2017]

Higgs, J., Jones, M.A., Loftus, S., and Christensen, N., (2018) Clinical Reasoning in the Health Professions E-Book. 3rd edn. Amsterdam: Elsevier/Butterworth-Heinemann

Hill, A.E., Davidson, B.J., McAllister, S., Wright, J., and Theodoros, D.G., (2014) 'Assessment of student competency in a simulated speech-language pathology clinical placement'. International Journal of Speech-Language Pathology, 16 (5), 464-475 https://doi.org/10.3109/17549507.2013.809603

Joseph, S., and Juwah, C. (2012) 'Using constructive alignment theory to develop nursing skills curricula'. Nurse Education in Practice, 12 (1) 52-59 https://doi.org/10.1016/j.nepr.2011.05.007

Lincoln, M., and McCabe, P. (2005) 'Values, necessity and the mother of invention in clinical education'. Advances in Speech Language Pathology, 7 (3), 153-157 https://doi.org/10.1080/14417040500181296

Mason, R., Vitkovitch, J., Lambert, R., and Jepson, J., (2016) 'Knowing about and performing professionalism: Developing professionalism in interprofessional healthcare education'. International Journal of Practice-Based Learning in Health and Social Care, 2 (1), 96107 https://doi.org/10.11120/pblh.2013.00027

McAllister, L., (1997) Facilitating Learning in Clinical Settings. Cheltenham: Nelson Thornes

McAllister, L. (2005) 'Issues and innovations in clinical education'. Advances in Speech Language Pathology, 7 (3), 138-148 https://doi.org/10.1080/14417040500181239

McAllister, L., and Rose, M. (2000) 'Speech-language pathology students: Learning clinical reasoning'. in Clinical Reasoning in the Health Professions. 3rd edn. ed. by Higgs, J., Jones, M.A., Loftus, S., and Christensen, N. Amsterdam: Elsevier/ButterworthHeinemann, 205-213 
MacBean, N., Theodoros, D., Davidson, B., and Hill, A.E. (2013) 'Simulated learning environments in speech-language pathology: An Australian response'. International Journal of Speech-Language Pathology, 15 (3), 345-357 https://doi.org/10.3109/17549507.2013.779024

McCurtin, A., and Carter, B. (2015) "We don't have recipes; we just have loads of ingredients": Explanations of evidence and clinical decision making by speech and language therapists'. Journal of Evaluation in Clinical Practice, 21 (6), 1142-1150 https://doi.org/10.1111/jep.12285

Mok, C.K., Whitehill, T.L., and Dodd, B.J., (2008) 'Problem-based learning, critical thinking and concept mapping in speech-language pathology education: A review'. International Journal of Speech-Language Pathology, 10 (6), 438-448 https://doi.org/10.1080/17549500802277492

Price, D., and Whiteside, M. (2016) 'Implementing the 2:1 student placement model in occupational therapy: Strategies for practice'. Australian Occupational Therapy Journal, 63 (2), 123-129 https://doi.org/10.1111/1440-1630.12257

Royal College of Speech and Language Therapists (2003) The provision of clinical placements: stakeholder roles and responsibilities. Position Paper. https://www.rcslt.org/docs/freepub/position paper clinical.pdf [18th March 2018]

Sheepway, L., Lincoln, M., and Togher, L.(2011) 'An international study of clinical education practices in speech-language pathology'. International Journal of Speech-Language Pathology, 13 (2), 174-185 https://doi.org/10.3109/17549507.2011.491129

Sinatra, G.M., and Mason, L. (2013) 'Beyond knowledge: Learner characteristics influencing conceptual change'. in International Handbook of Research on Conceptual Change, 2nd edn. ed. by Vosniadou, S. New York: Routledge, 377-394

Thew, M., Hargreaves, A., and Cronin-Davis, J. (2008) 'An evaluation of a role-emerging practice placement model for a full cohort of occupational therapy students'. British Journal of Occupational Therapy, 71 (8), 348-353 https://doi.org/10.1177/030802260807100809

Trigwell, K., Prosser, M., and Waterhouse, F. (1999) 'Relations between teachers' approaches to teaching and students' approaches to learning'. Higher Education, 37 (1), 57-70 https://doi.org/10.1023/A:1003548313194

Tripp, T.R., and Rich, P.J. (2012) 'The influence of video analysis on the process of teacher change'. Teaching and Teacher Education, 28 (5), 728-739 https://doi.org/10.1016/i.tate.2012.01.011

Vosniadou, S. (2013) 'Conceptual change research: an introduction'. in International Handbook of Research on Conceptual Change, 2nd edn. ed. by Vosniadou, S. New York: Routledge, 13-20 https://doi.org/10.4324/9780203154472

Vosniadou, S. (2014) 'Examining cognitive development from a conceptual change point of view: The framework theory approach'. European Journal of Developmental Psychology, 11 (6), 645-661 https://doi.org/10.1080/17405629.2014.921153

Wenger, E. (2011) 'Communities of practice: A brief introduction'. Retrieved from https://scholarsbank.uoregon.edu/xmlui/bitstream/handle/1794/11736/A\%20brief\%20int roduction\%20to\%20CoP.pdf [15th March 2018] 